\title{
PERAN REKRUTMEN DAN PENEMPATAN KERJA PADA PT. INDOMARCO ADI PRIMA SURABAYA
}

\author{
Novika Nur Rohmah \\ Universitas Negeri Surabaya \\ novikaoppo@gmail.com \\ Agus Frianto \\ Universitas Negeri Surabaya \\ agusfrianto@unesa.ac.id
}

\begin{abstract}
This study examines the role of recruitment and job placement at PT. Indomarco Adi Prima Surabaya influence work productivity. This research with a quantitative approach has 60 populations. The tests performed were data analysis of validity, reliability, and classic assumption tests, including normality test, autocorrelation test, multicollinearity test, and heteroscedasticity test. Furthermore, hypothesis testing includes test (R2), $T$ statistical test, F statistical test, and multiple linear regression test. Data collection use observations, interviews and (primary) questionnaires. Data analysis use multiple linear regression with SPSS (v.18). The results showed that partially and simultaneously, the variables of recruitment and job placement had a significant positive effect on employee work productivity. Partially the better the recruitment system, the better work productivity will be. Likewise, a good job placement will increase employee work productivity. Furthermore, simultaneously the variable recruitment and good work placement will increase employee productivity.
\end{abstract}

Keywords: employee productivity; job placement; recruitment

\section{PENDAHULUAN}

Berjalannya revolusi industri 4.0 berbasis cyber physical pada saat ini, membuat persaingan dunia semakin kompetitif. Revolusi 4.0 akan mengaitkan pekerjaan pada keahlian ilmu pengetahuan, teknologi, dan internet of things (Zimmerman, 2018). Tidak bertumpu pada perkembangan teknologi, pelaksanaan revolusi industri pasti melibatkan sumber daya manusia yang merupakan pemeran industri 4.0 (Saputra, 2019). Tanpa sumber daya manusia yang mumpuni, teknologi yang canggih akan menjadi percuma, karena penggunaan manusia dalam organisasi dapat menyediakan sebuah keunggulan kompetitif, baik domestik maupun luar negeri (Muliawaty, 2019). Sehingga, sumber daya manusia dijadikan pegangan perusahaan dalam menciptakan keunggulan bersaing dan kualitas tenaga kerja harus dikembangkan dan diperbaiki agar dapat menciptakan produktivitas dalam tingkat yang optimal.

Pada perusahaan modal utama yang harus ada dan harus dicermati yaitu sumber daya manusia, karena memiliki peran strategis untuk perusahaan dalam mencapai tujuan (Saretta, 2019). Globalisasi memunculkan paradigma bahwa peran manusia merupakan arah paling strategis dan merupakan aset dan dasar keunggulan kompetitif dari organisasi (Muliawaty, 2019). Aktivitas pengelolaan SDM yang dapat menghasilkan produktivitas kerja karyawan berkualitas adalah rekrutmen, penyaringan, dan penempatan (Atmajati \& Mansur, 2017). Rekrutmen merupakan tahap awal dan dianggap sangat penting dalam kegiatan pengelolaan sumber daya manusia. Akurasi rekrutmen dapat meningkatkan keefektifan dan efisensi operasional, dan teknik rekrutmen juga akan berdampak pada produktivitas perusahaan (Pranoto et al., 2016). Baik tidaknya perusahaan dari pandangan publik dapat dilihat dari produktivitas perusahaan yang di dalamnya didukung produktivitas karyawan yang berkompeten. Oleh karena itu, rekrutmen memiliki andil dalam menjalankan tujuan perusahaan. Dari rekrutmen dapat tercipta citra perusahaan dengan melihat kualifikasi yang ditentukan untuk memeroleh tenaga kerja yang berpotensi mendukung visi misi perusahaan. Selama 20 tahun terakhir, sering muncul literatur yang berkembang tentang cara di mana praktik sumber daya manusia berdampak positif pada produktivitas organisasi atau perusahaan. Penelitian sebelumnya telah menunjukkan hasil konseptualisasi rekrutmen bahwa rekrutmen dapat menciptakan efek sinergis dan merupakan aktifitas 
Novika Nur Rohmah \& Agus Frianto. Peran Rekrutmen dan Penempatan Kerja Pada PT. Indomarco Adi Prima Surabaya

yang mampu membangun opini masyarakat yang dianggap menguntungkan karena dengan cara memengaruhi sikap pelamar dalam beberapa cara, terlepas apakah mereka dipilih perusahaan atau tidak (Sabrina, 2018).

Penelitian lain menunjukkan bahwa rekrutmen menimbulkan hasil yang bertentangan bagi produktivitas kerja karyawan. Rekrutmen tidak selalu berpengaruh secara positif dan signifikan terhadap produktivitas kerja karyawan. Perusahaan memiliki cara atau peluang dengan mempertimbangkan faktor lain yang dapat meningkatkan produktivitas seperti mencari sumber masalah yang menghambat produktivitas, mengidentifikasi masalah dan menindak lanjuti sumber masalah, menghindari kondisi beresiko dengan membuat lingkungan kerja yang nyaman, serta memberi intensif kehadiran dalam bentuk reward dan tambahan gaji (Afriandi, 2017). Faktor - faktor yang memengaruhi rekrutmen yaitu situasi ekonomi negara secara keseluruhan. Jika kondisi ekonomi relatif sulit, biasanya terjadi situasi kelebihan pasokan, atau jumlah pekerja yang diharapkan jauh lebih banyak dari jumlah yang dibutuhkan. Jika hal ini terjadi maka perusahaan dengan mudah mencari karyawan baru karena jumlah pencari kerja yang banyak. Faktor kedua adalah ketersediaan tenaga kerja di bidang yang diminati. Jika bidang yang dicari merupakan bidang yang langka maka akan lebih sulit bagi perusahaan untuk bertemu dengan karyawan (Pranoto et al., 2016).

Pelaksanaan rekrutmen dapat dijadikan sebagai pedoman penempatan karyawan karena dapat berpengaruh pada kenaikan produktivitas karyawan (Sarinah, Gultom R \& Thabah, A, 2016). Prinsip the right man on the right place menjadi pegangan manajer personalia dalam menempatkan karyawan. Kegagalan ketika rekrutmen dan penempatan kerja akan memengaruhi kinerja yang nantinya menjadi penghambat pencapaian tujuan perusahaan. Produktivitas ialah dimensi yang ditetapkan untuk melihat bagaimana mutu sumber daya manusia dipunyai dan dimanfaatkan demi memeroleh hasil maksimal (Siregar et al., 2020) .

Persentase produktivitas tenaga kerja Indonesia yang mencapai $74,4 \%$ masih dibawah rata - rata produktivitas tingkat ASEAN yang berada di nilai 78,2\% membuat pemerintah berupaya untuk meningkatkan produktivitas. Ditambah dampak pandemi Covid-19 menyebabkan 3,1 juta pekerja dirumahkan dan di PHK, sehingga pemerintah menerbitkan UU Cipta Kerja yang bertujuan menyederhanakan, menyingkronkan, dan memangkas regulasi yang menghambat penciptaan lapangan kerja sebagai upaya penciptaan tenaga kerja terampil dan menciptakan lingkungan hidup ketenagakerjaan itu sendiri (Natalia, 2020). Penelitian ini bermaksud melihat pengaruh dari rekrutmen dan penempatan kerja terhadap produktivitas kerja karyawan di PT.Indomarco Adi Prima Surabaya yang terletak di Jl. Rungkut Industri Raya No. 11 A, Surabaya, Jawa Timur. PT. Indomarco Adi Prima ialah perusahaan yang berkecimpung pada bidang distribusi dan impor produk konsumen khususnya produk indofood. PT. Indomarco Adi Prima merupakan salah satu distributor PT. Indofood Sukses Makmur dengan jaringan distribusi terluas di Indonesia. Perusahaan yang bergantung pada cara kerja karyawan ini, memandang bahwa produktivitas karyawan merupakan hal utama yang harus diperhatikan.

Menurut hasil wawancara kepada bapak Hasan salah satu kayawan tetap selama 28 tahun, saat ini produktivitas karyawan diperoleh dari analisis kualifikasi pada rekrutmen dan penempatan kerja dengan melihat keterampilan dan pengalaman yang berpengaruh pada produktivitas kerja, menurut beliau meski ditempatkan pada posisi atau jabatan apapun tanpa pengetahuan dan pengalaman maka karyawan tersebut tidak dapat bekerja dengan baik dan hasilnya tidak memuaskan. Begitu juga pendapat Pak Arif Ramdan selaku karyawan tetap staff HRD sejak 2017, kualifikasi pada rekrutmen dan penempatan kerja secara umum berdampak pada produktivitas dilihat dari pengalaman dan pendidikan karyawan.Semua tergantung kepada individu meskipun pengalaman atau background tidak sesuai pekerjaan yang sekarang tetapi individu tersebut ingin dan mau berkembang, maka tidak akan berpengaruh kepada produktivitas meskipun kesulitan di awal masuk kerja saja. produktivitas kerja tidak sekedar bertujuan untuk mendapatkan pekerjaan yang sebanyak-banyaknya, namun lebih kepada kualitas pekerjaan yang juga penting untuk diperhatikan (Elqadri et al., 2015). Berdasarkan fenomena tersebut, penelitian ini bertujuan untuk menemukan pengaruh rekrutmen dan penempatan kerja terhadap produktivitas kerja PT. Indomarco Adi Prima Surabaya. 
Novika Nur Rohmah \& Agus Frianto. Peran Rekrutmen dan Penempatan Kerja Pada PT. Indomarco Adi Prima Surabaya

\section{KAJIAN PUSTAKA DAN PENGEMBANGAN HIPOTESIS}

\section{Rekrutmen}

Rekrutmen diidentifikasi sebagai proses mengumpulkan banyak pelamar kerja dengan kualifikasi yang dibutuhkan perusahaan untuk dipekerjakan (Sarinah, Gultom R \& Thabah, A, 2016). Rekrutmen juga didefinisikan sebagai rangkaian kegiatan yang bertujuan untuk memilih dan memikat pelamar kerja yang memiliki motivasi, kapabilitas, keterampilan, pengetahuan dari rencana kepegawaian yang kekurangan. Kegiatan rekrutmen dimulai dengan mencari kandidat dan diakhiri saat mereka mengajukan lamaran (Sunarsi, 2018). Perekrutan merupakan cara menghasilkan kumpulan kandidat yang memenuhi syarat untuk mengisi peluang kerja (Siregar et al., 2020). Perekrutan merupakan proses atau tindakan yang dilakukan perusahaan untuk menarik lebih banyak karyawan dengan melalui tahap mengidentifikasi dan mengevaluasi sumber penarikan karyawan, menentukan kebutuhan perusahaan akan karyawan, proses seleksi, penempatan karyawan dan pelatihan (Sari, 2018). Tujuan dari proses rekrutmen adalah mengumpulkan calon karyawan yang banyak, sehingga perusahaan mempunyai peluang lebih tinggi untuk menemukan karyawan yang masuk kriteria yang dipersyaratkan, dan pada akhirnya memungkinkan karyawan yang berkualitas untuk memercepat realisasi tujuan perusahaan (Atmajati \& Mansur, 2017).

Indikator rekrutmen yang dikembangkan oleh Sunarsi (2018) ada 3 yaitu: dasar sumber penarikan karyawan berpedoman pada posisi atau spesifikasi pekerjaan; sumber karyawan, termasuk sumber internal dan eksternal perusahaan (sumber internal berupa promosi jabatan, rotasi/ transfer, dll, sedangkan sumber eksternal berasal dari rekomendasi, lembaga departemen, organisasi profesi dan keahlihan, serta asosiasi pekerja); dan metode penarikan karyawan, berupa strategi rekrutmen menggunakan iklan, rekomendasi perusahaan internal, penyedia tenaga kerja, institut pendidikan, instansi pemerintah, daya usaha pelamar dan media sosial. Dalam melakukan rekrutmen terdapat beberapa tahapan yang juga dipengaruhi oleh faktor seperti ketersediaan tenaga kerja yang dibutuhkan perusahaan.

\section{Penempatan Kerja}

Keberhasilan penyediaan tenaga kerja berada pada penempatan karyawan yang benar, baik itu karyawan baru atau karyawan lama pada jabatan baru. Penempatan kerja sangat penting karena perusahaan dapat beroperasi jika semua jabatan ada pejabatnya (Atmajati \& Mansur, 2017). Menurut (Praskova et al., 2015) perencanaan penempatan sebelumnya harus dimulai dari mengamati sejauh mana pengalaman dan pendidikan yang dimiliki seorang karyawan. Hal tersebut akan memudahkan dalam mengamati jalur karier karyawan. Penempatan karyawan adalah adalah proses pemberian tugas dan pekerjaan kepada karyawan yang lulus seleksi untuk dilaksanakan sesuai ruang lingkup yang telah ditetapkan, serta mampu tanggung jawab atas segala resiko (Suwarto, 2015). Prinsip penempatan kerja dilakukan agar karyawan bekerja sejalan dengan tujuan perusahaan. Memiliki posisi kerja yang tepat dapat meningkatkan semangat kerja karyawan dan mendukung prestasi karyawan. Intinya pada penempatan kerja karyawan, yaitu menempatkan karyawan pada tempat yang benar. Penempatan tenaga kerja dimaksudkan untuk menempatkan tenaga kerja sebagai unsur pelaksana pekerjaan pada posisi yang sesuai dengan kemampuan, kecakapan, dan keahliannya (Sari, 2018).

Jika perekrutan sukses atau banyak pencari kerja mencalonkan diri, perusahaan akan memiliki lebih banyak kesempatan untuk merekrut karyawan terbaik (Mey, 2017). Dengan demikian produktivitas karyawan dan perusahaan dapat terus meningkat. Dapat dipahami bahwa penempatan pegawai tidak hanya sebatas menempatkan saja, melainkan harus mencocokan dan membandingkan kualifikasi yang dimiliki pegawai dengan kebutuhan dan persyaratan dari suatu jabatan atau pekerjaan, sehingga the right man on the right job tercapai. Menurut (Haryati \& Hajar, 2016) penempatan kerja diartikan sebagai perlakuan kebijaksanaan kepada sumber daya manusia untuk menentukan posisi atau jabatan.

Indikator penempatan kerja yang dikembangkan oleh (Haryati \& Hajar, 2016) yaitu: (1) Pendidikan, wajib dimiliki karyawan yang dipersyaratkan termasuk pendidikan yang harus dilaksanakan serta pembelajaran pengganti yaitu apabila pendidikan lain terpaksa dilaksanakan. (2) Pengetahuan kerja yang secara alamiah oleh karyawan harus dimiliki merupakan pengetahuan sebelum penempatan, yang hanya dapat diperoleh pada saat karyawan tersebut bekerja. (3) Keterampilan kerja, mencakup 
kecakapan atau pengetahuan profesional yang didapat saat praktik, keterampilan kerja tersebut dibedakan tiga kategori yaitu: keterampilan mental, semacam analisis dan pengambilan keputusan; keterampilan fisik, seperti memerbaiki kelistrikan, mekanik, dll; keterampilan sosial, semacam memengaruhi orang lain, menyediakan barang atau jasa; dan pengalaman kerja, mengacu pada pengalaman karyawan dalam pekerjaan tertentu yang mampu dijadikan pertimbangan untuk mengatur tugas dan waktu untuk menyelesaikan pekerjaan.

\section{Produktivitas Kerja Karyawan}

Menurut (Sari, 2020) produktivitas adalah hasil kerja karyawan. Hasil kerja karyawan adalah proses kerja seseorang saat memproduksi barang atau jasa. Produktivitas karyawan diartikan sejauh mana karyawan berkontribusi dalam mencapai tujuan organisasi. Maka dari itu, produktivitas karyawan diukur dengan kuantitas dan kualitas pekerjaan dilakukan secara efektif dan efisien dengan biaya sumber daya yang minimal (Abiodun et al., 2020). Selain membandingkan efektivitas hasil input dan output, produktivitas juga didefinisikan sebagai menentukan tujuan yang efektif, membuat rencana, menggunakan metode produktif untuk menggunakan sumber daya secara efektif dan mempertahankan metode disipliner berkualitas tinggi (Haryati \& Hajar, 2016). Produktivitas adalah hasil kerja secara kualitas dan kuantitas yang dicapai oleh seorang pegawai dalam melaksanakan tugasnya sesuai dengan tanggung jawab yang diberikan. Produktivitas tenaga kerja adalah salah satu ukuran perusahaan dalam mencapai tujuannya. Sumber daya manusia merupakan elemen yang paling strategik dalam organisasi, harus diakui dan diterima oleh manajemen (Suwarto, 2015). Dalam menjalankan tugasnya, diharapkan seorang karyawan dapat menunjukkan kinerja yang baik, selain itu performance yang ditunjukan oleh seorang karyawan tentu saja dipengaruhi oleh berbagai faktor yang penting artinya bagi peningkatan hasil kerja yang menjadi tujuan dari organisasi di mana pegawai tersebut bekerja.

Faktor - faktor yang memengaruhi produktivitas kerja (Haryati \& Hajar, 2016) yaitu: latihan kerja, dimaksudkan untuk memberikan pelengkap dasar - dasar pengetahuan agar karyawan belajar mengerjakan pekerjaan dengan benar - benar tepat dan dapat meminimalisir terjadinya kesalahan; mental dan kemampuan fisik karyawan. Keadaan fisik dan mental karyawan memiliki hubungan yang sangat erat dengan produktivitas. Hubungan atasan dan bawahan memengaruhi aktivitas sehari-hari. Apa pendapat atasan tentang bawahan, dan tingkat keterlibatan bawahan dalam menetapkan tujuan. Sikap yang saling terkait ini dapat meningkatkan produktivitas kerja karyawan. Oleh karena itu, jika karyawan diperlakukan dengan baik, karyawan tersebut juga akan berpartisipasi dalam proses produksi dengan tepat sehingga memengaruhi produktivitas kerja karyawan.

Indikator pengukuran produktivitas kerja menurut (Sari, 2018) yaitu (1) Kemampuan, kekuatan keterampilan dan profesionalitas karyawan yang dianggap mampu mengatasi pekerjaan yang dibebankan. (2) Meningkatkan hasil yang diperoleh. Mencoba lebih baik dan tingkatkan jumlah maksimal dari hari kemarin. (3) Semangat kerja. Etos kerja yang lebih baik untuk dapat memberi kontribusi lebih banyak ke perusahaan. (4) Pengembangan diri. Meningkatkan kemampuan dengan menghadapi tantangan yang ada. Semakin kuat tantangan, pengembangan diri senantiasa dilakukan dan berdampak pada keinginan harapan yang lebih baik. (5) Mutu, yang menunjukkan kualitas pekerjaan. (6) Efisien, membandingkan hasil yang dicapai dan total sumber daya yang terpakai. Input dan output adalah bagian dari produktivitas dan berpengaruh signifikan bagi karyawan.

\section{Hubungan antar Variabel}

Rekrutmen dapat memengaruhi produktivitas karyawan. Dibuktikan dengan hasil penelitian (Sunarsi, 2018) pada PT Mercolade Tangerang, bahwa secara parsial rekrutmen mampu memengaruhi produktivitas kerja karayawan. Berdasarkan hasil jawaban seluruh karyawan yang berjumlah 100 orang dengan 10 pertanyaan yang menjawab "setuju" setuju dengan skor $160(32,0 \%)$, namun masih terdapat 11 jawaban "Sangat Tidak Setuju" pada indikator "perusahaan merekrut karyawan dari sumber eksternal (iklan, outsourcing)" sehinggga sebaiknya PT Mercolade Tangerang lebih menekankan dan memberikan kesempatan untuk orang lain yang bekerja diperusahaan ini dari sumber eksternal seperti iklan di media. Sejalan dengan Pranoto et al. (2016) hasil positif signifikan pada rekrutmen terhadap produktivitas kerja karyawan pada PT. Ungaran Sari Garment Congol Karangjati dengan pelaksanaan rekrutmen sesuai job descrition dan seleksi untuk memeroleh karyawan 
Novika Nur Rohmah \& Agus Frianto. Peran Rekrutmen dan Penempatan Kerja Pada PT. Indomarco Adi Prima Surabaya

berkualitas. Penelitian Atmajati \& Mansur (2017), secara parsial rekrutmen berpengaruh terhadap produktivitas pada PT. Bank papua Jayapura ketika mereka melihat dan mengutamakan indikator mutu karyawan dan analisis pekerjaan. Begitu pula Abiodun et al. (2020) pada pelayanan bea cukai di Nigerian terdapat pengaruh signifikan positif antara rekrutmen terhadap produktivitas kerja karyawan. Re-praktik manajemen sumber memiliki pengaruh yang lemah terhadap produktivitas karyawan di NCS. Studi tersebut merekomendasikan bahwa kepemimpinan NCS untuk mengadopsi praktik strategis manajemen sumber daya manusia, salah satu yang mengidentifikasi diperlukan kebutuhan sumber daya manusia melalui proses etika dan mengidentifikasi bidang kebutuhan sumber daya manusia dan program pelatihan khusus untuk membantu perbaikan memperbaiki energi personelnya untuk memberikan layanan publik kelas dunia yang superior.

Berlainan dengan penelitian Lestari et al. (2018), sistem rekrutmen di PT. Ladang Hijau tidak berpengaruh pada produktivitas kerja karyawan. Pada PT. Ladang hijau sumber penarikan karyawan pabrik yang dilakukan secara internal menyebabkan sistem rekrutmen tidak berpengaruh pada produktivitas kerja karyawan, di mana tidak ada kriteria tertentu untuk karyawan baru di bagian pabrik. Sehingga sistem rekrutmen yang dilakukan oleh perusahaan berdampak sama pada produktivitas semua karyawan yang bekerja di PT. Ladang Hijau. Pranutoko (2016) mengungkapkan bahwa sistem rekrutmen berpengaruh negatif terhadap produktivitass kerja karyawan. Sistem penarikan dengan metode penarikan rekomendasi karyawan lama memiliki pengaruh positif, namun pengaruh negatif terjadi antara proses rekrutmen melalui info lowongan kerja terhadap produktivitas kerja di UD Berkah Mulia Kediri. Sehingga karyawan yang didapat melalui info lowongan kerja memberikan dampak penurunan produktivitas kerja karyawan di UD Berkah Mulia Kediri.

H1 : Rekrutmen berpengaruh signifikan positif terhadap produktivitas kerja karyawan di PT. Indomarco Adi Prima.

Dalam menghasilkan karyawan berkompeten, diperlukan pemahaman mendalam saat tahap pengisian jabatan untuk karyawan. Menurut Haryati \& Hajar (2016) fenomena yang terjadi saat ini adalah penempatan pegawai tidak berdasarkan standar jabatan, tetapi berdasarkan otoritas atasan dan pengaruh kerabat yang bekerja di perusahaan. Sehingga produktivitas karyawan tidak meningkat. Sesuai pernyataan tersebut diartikan bahwa penempatan merupakan perlakuan bijak untuk sumber daya manusia untuk meningkatkan produktivitas.

Bagaimana menempatkan orang di tempat yang tepat keterampilannya sering menjadi elemen terpenting dalam mengelola sumber daya manusia. Jika karyawan sebagai individu tidak dapat menyesuaikan diri, maka mereka bisa melihatnya sebagai tekanan yang mengancamnya yang akan menyebabkan tekanan seiring waktu untuk karyawan yang relevan Agustriyana (2015). Dibutuhkan kontribusi rekrutmen dan seleksi untuk membantu penempatan karyawan, yang mana rekrutmen dapat memberikan rekomendasi karyawan untuk menempati suatu jabatan Sarinah et al. (2016).

Haryati \& Hajar (2016) mengemukakan bahwa penempatan kerja membawa pengaruh positif signifikan terhadap produktivitas kerja di PT. Pelabuhan Indonesia I (Persero). Atmajati \& Mansur (2017) mengemukakan secara parsial penempatan kerja berpengaruh terhadap produktivitas pada PT. Bank papua Jayapura. Pengaruh positif secara parsial penempatan kerja dan produktivitas kerja juga dilakukan Mandik \& Sendow (2019) pada PT. PLN (Persero) Rayon Maniki Manado. Informasi harus diberikan kepada setiap perekrut PLN, terutama yang berpendidikan D3 / S1 / S2 terkini, sehingga mereka bersedia ditempatkan di seluruh Indonesia. Alasan penempatan tersebut karena mencakup sejumlah besar unit PLN di hampir seluruh wilayah Indonesia, dan kebijakan penempatan kerja diarahkan pada kapabilitas pengembangan profesional karyawan. "Karena setiap departemen memiliki tantangan dan budaya yang berbeda, maka hard skill, soft skill, dan kinerjanya telah teruji di setiap departemen tempat karyawan bekerja". Berbeda dengan Suwarto (2015) mengutarakan pengaruh signifikan negatif pada penempatan kerja terhadap produktivitas karyawan di BMT Familier Kota Gajah Lampung Tengah akibat belum sepenuhnya konsep penempatan karyawan dilaksanakan dengan baik seperti menyesuaikan ketepatan latar belakang pendidikan, kemampuan dan keahlian.

H2 : Penempatan kerja berpengaruh signifikan positif terhadap produktivitas kerja karyawan di PT. Indomarco Adi Prima. 
Novika Nur Rohmah \& Agus Frianto. Peran Rekrutmen dan Penempatan Kerja Pada PT. Indomarco Adi Prima Surabaya

Ada beberapa tolok ukur untuk meningkatkan produktivitas kerja termasuk fungsi manajemen sumber daya manusia yang sesuai yaitu rekrutmen dan penempatan pekerja, dan hubungan langsung antara perusahaan dan konsumen atau penggunaan layanan (melalui karyawan yang ditempatkan di posisinya masing-masing). Dalam hal memberikan pelayanan terbaik kepada perusahaan dan konsumen sangat erat kaitannya dengan produktivitas karyawan (Suwarto, 2015). Pada pengelolaan sumber daya manusia, untuk mendapatkan sumber daya manusia yang berkualitas dengan produktivitas karyawan, perlu dilakukan perekrutan dan pengalokasian atau penempatan tenaga kerja untuk mencapai tujuan perusahaan. (Syafitri \& Chairoel, 2019).

Syafitri \& Chairoel (2019) mengemukakan hasil rekrutmen bersama penempatan kerja berpengaruh signifikan dan positif secara simultan terhadap produktivitas kerja di Bank Syariah Mandiri Cabang Padang. Rekrutmen bersama penempatan kerja secara simultan yang berpengaruh positif signifikan juga dilakukan Din \& Sumarauw (2018) di PT. HM. Sampoerna Tbk meskipun secara parsial variabel rekrutmen berpengaruh negatif. Hal yang sama juga terjadi pada Sarinah, et al. (2016) bahwa rekrutmen bersama variabel seleksi berpengaruh terhadap produktivitas kerja karyawan melalui penempatan kerja di PT. Sriwijaya Air. Sari (2018) yang mengemukakan secara simultan rekrutmen dan penempatan kerja mampu memengaruhi secara signifikan positif terhadap produktivitas kerja karyawan di PT. Sindang Brothers Kota Lubuklinggau.

H3 : Rekrutmen dan penempatan kerja memiliki pengaruh signifikan positif terhadap produktivitas kerja karyawan PT. Indomarco Adi Prima.

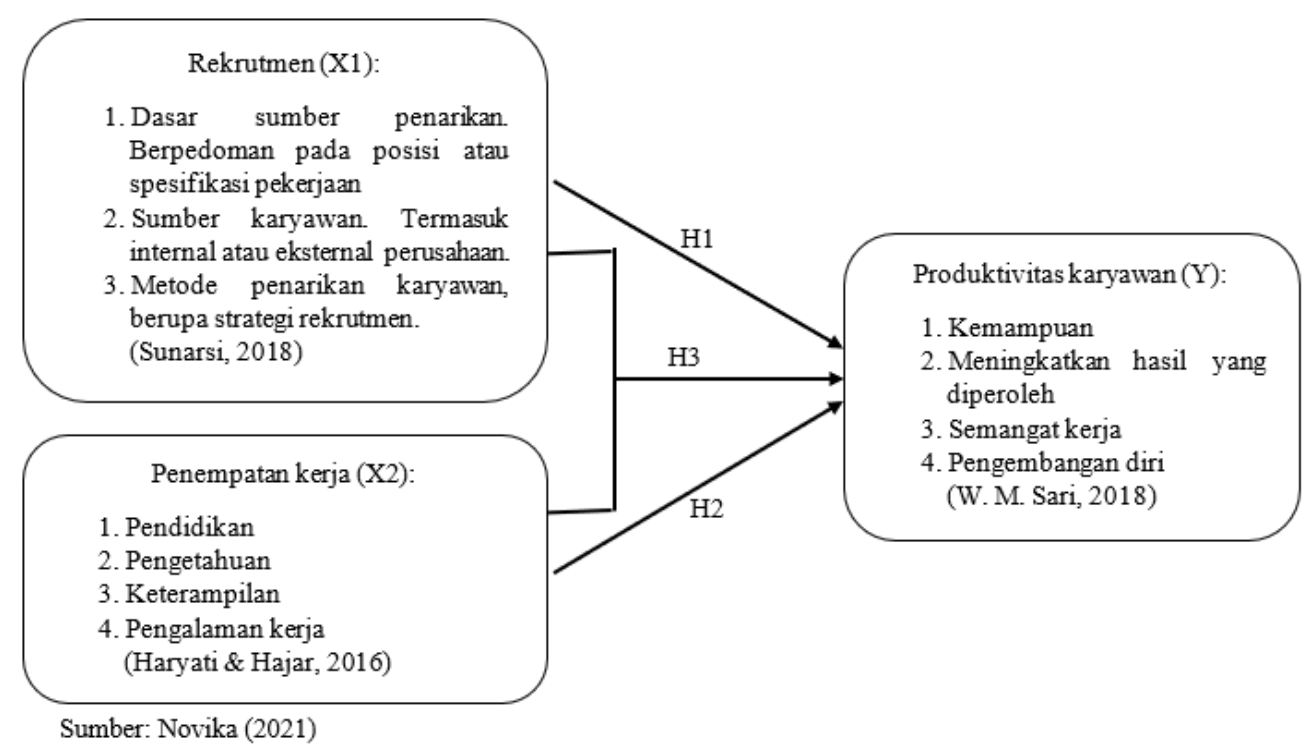

Gambar 1. KERANGKA KONSEPTUAL

\section{METODE PENELITIAN}

Penelitian ini termasuk dalam kategori penelitian kuantitatif dengan menggunakan data primer yang merupakan data hasil observasi langsung dengan objek penelitian dan data sekunder yang berasal dari sumber literasi sebagai pelengkap. Pengumpulan data tersebut dilakukan dengan metode observasi, wawancara, dan kuesioner. Variabel penelitiannya yaitu variabel rekrutmen (X1), variabel penempatan kerja (X2) dan variabel produktivitas kerja (Y). Objek penelitian adalah PT. Indomarco Adi Prima Surabaya. Populasi penelitian ini memiliki ukuran sampel 60 karyawan tetap yang seluruhnya dijadikan sampel penelitian. Pengambilan sampel penelitian ini memakai metode probability sampling dengan teknik simple random sampling. Metode sampel jenis ini dilakukan dengan memberikan kesempatan yang sama pada semua elemen untuk dapat dipilih sebagai sampel. Pengujian data pada penelitian ini yaitu uji validitas, uji reliabilitas, uji asumsi klasik yang meliputi 
Novika Nur Rohmah \& Agus Frianto. Peran Rekrutmen dan Penempatan Kerja Pada PT. Indomarco Adi Prima Surabaya

uji multikolinieritas, uji normalitas, autokorelasi, dan uji heterokedastisitas. Selanjutnya dilakukan uji hipotesis yang meliputi uji $\left(\mathrm{R}^{2}\right)$, uji statistik $\mathrm{T}$, uji statistik $\mathrm{F}$, dan regresi linier berganda. Skala pengukuran penelitian ini memakai skala likert 1-5 dengan rentang skala berawal dari skala 1 (sangat tidak setuju) sampai dengan skala 5 (sangat setuju). Pengolahan data penelitian menggunakan program SPSS (v.18).

\section{HASIL DAN PEMBAHASAN}

\section{Hasil Uji Validitas}

Uji validitas bertujuan untuk menguji kelayakan pernyataan dalam angket dengan perbandingan $\mathrm{r}$ hitung dan r-tabel, sehingga dapat mengungkap isi yang akan diukur dengan angket. Ketentuan rtabelnya jika jumlah responden 30 untuk uji validitas dengan tingkat kesalahan 5\% $(0,05)$ adalah 0,374 yang diperoleh dari $\mathrm{DF}=\mathrm{N}-2$, sehingga $\mathrm{DF}=30-2=28$. Dikatakan valid jika $\mathrm{r}$ hitung $>\mathrm{r}$ tabel. Hasil validasi X1, X2 dan Y dinyatakan valid karena semua pernyataan memiliki nilai > 0,374.

\section{Hasil Uji Realibilitas}

Uji realibilitas yaitu menguji bagaimana alat ukur dapat dipercaya dan diandalkan dengan melihat nilai Cronbach's Alpha yang mana jika nilai tersebut $>0,70$ maka semua item dapat digunakan sebagai alat ukur. Nilai Cronbach's Alpha dari X1 atau rekrutmen yaitu 0,827, sedangkan nilai dari $\mathrm{X} 2$ atau penempatan kerja yaitu 0,869 , dan nilai dari $\mathrm{Y}$ atau produktivitas kerja karyawan yaitu 0,934 .

\section{Hasil Uji Asumsi Klasik}

Tabel 1, hasil uji normalitas menggunakan Kolmogorov-smirnov (KS) memeroleh signifikansi 0,754 atau $>0,05$. Artinya data terdistribusi normal. Uji autokorelasi menggunakan Durbin-watson (DW) memeroleh nilai 2,270 dengan derajat kepercayaan $5 \%(\alpha=0,05)$, dengan jumlah variabel independen $(\mathrm{k})=2$ dan total $(\mathrm{N})=60$ apabila dimasukkan ke dalam persamaan $\mathrm{du}<\mathrm{d}<4$ - du menjadi 1,6518< $2,270<2,3482$. Dari persamaan tersebut tidak ditemukan autokorelasi. Uji multikolinieritas menunjukkan nilai tolerance $>0,1$ dari keseluruhan variabel independen, dan hasil VIF $<10$, Jadi tidak terindikasi multikolinieritas. Uji heteroskedastisitas dengan uji spearman menunjukkan nilai signifikansi dari seluruh variabel independen $>0,05$ maknanya bebas dari gejala heteroskedastisitas.

Tabel 1.

\section{HASIL UJI ASUMSI KLASIK}

\begin{tabular}{lccccc}
\hline \multicolumn{1}{c}{ Variabel } & Normalitas & Autokorelasi & \multicolumn{2}{c}{ Multikolinieritas } & Heteroskedastisitas \\
& Sig. & $\boldsymbol{D W}$ & Tolerance & VIF & Sig. \\
\hline \multirow{2}{*}{$\begin{array}{c}\text { Rekrutmen } \\
\text { Penempatan Kerja }\end{array}$} &, 754 & 2,270 & & & \\
& & &, 679 & 1,472 &, 933 \\
& & &, 679 & 1,472 &, 709 \\
\hline
\end{tabular}

Sumber : Output SPSS (2021, data diolah)

\section{Hasil Uji Hipotesis}

Berdasarkan tabel 2, hasil uji determinasi $\left(\mathrm{R}^{2}\right)$ sebesar 0,446 atau 44,6\% yang berarti kemampuan yang dimiliki model dalam menjelaskan variabel rekrutmen dan penempatan kerja untuk menerangkan versi variabel dependen sebesar 44,6\%, sedangkan sisanya 55,4\% dijelaskan oleh sebab lain di luar model yang tidak diteliti.

Berdasarkan uji regresi linier berganda mendapat model persamaan produktivitas kerja karyawan, pada persamaan (1):

$\mathrm{Y}=15,247+0,564 \cdot \mathrm{X} 1+0,485 \cdot \mathrm{X} 2+\mathrm{e}$

Dari persamaan (1) jika rekrutmen dan penempatan kerja tidak dilakukan atau nilainya 0 maka produktivitas kerja karyawan meningkat sebesar 15,247. Artinya karyawan tetap bekerja sesuai prosedur perusahaan meskipun rekrutmen dan penempatan kerja tidak sesuai dengan standart perusahaan. Variabel rekrutmen memiliki koefisien regresi positif. Artinya apabila rekrutmen 
Novika Nur Rohmah \& Agus Frianto. Peran Rekrutmen dan Penempatan Kerja Pada PT. Indomarco Adi Prima Surabaya

meningkat $1 \%$, maka produktivitas kerja karyawan akan meningkat sebesar 0,485 . Untuk variabel penempatan kerja berpengaruh positif terhadap produktivitas kerja karyawan dengan nilai koefisien 0,564. Artinya jika variabel penempatan kerja meningkat satu-satuan dengan asumsi bahwa variabel rekrutmen tetap, maka produktivitas kerja karyawan meningkat sebesar 0,564.

Tabel 2.

HASIL UJI HIPOTESIS

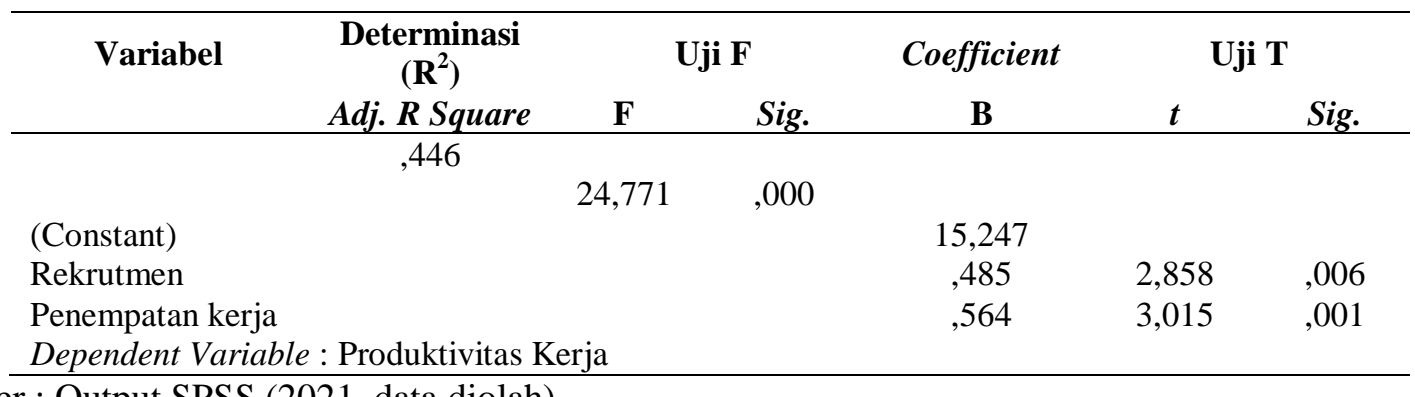

Sumber : Output SPSS (2021, data diolah)

Tabel 2, hasil uji t secara parsial bahwa variabel rekrutmen berpengaruh signifikan positif terhadap produktivitas kerja karyawan karena nilai t-hitung 2,858 > 2,002 t-tabel dan signifikansi 0,006 atau < 0,05 . Begitu juga penempatan kerja memiliki pengaruh signifikan positif secara parsial terhadap produktivitas kerja karyawan dengan perolehan nilai t-hitung 3,015>2,002 t-tabel dan signifikansinya $0,001<0,05$

Uji $\mathrm{F}$ memeroleh nilai signifikansi sebesasr $0,000<0,05$ dan nilai $\mathrm{F}$ hitung yaitu 24,771 > 3,15 F tabel. Sehingga rekrutmen dan penempatan kerja secara bersama-sama (simultan) berpengaruh terhadap produktivitas kerja karyawan.

\section{Pengaruh Rekrutmen terhadap Produktivitas Kerja Karyawan}

Sesuai hasil uji yang dilakukan, rekrutmen berpengaruh signifikan positif secara parsial terhadap produktivitas kerja karyawan, hal ini berarti $\mathrm{H} 1$ diterima. Penelitian diperkuat oleh Pranoto et al. (2016), Atmajati \& Mansur (2017), Sunarsi, (2018) dan Abiodun et al. (2020) yang mengungkapkan rekrutmen berpengaruh pada produktivitas kerja karyawan. Di mana semakin baik pelaksanaan rekrutmen maka akan meningkatkan produktiviats kerja. Rekrutmen merupakan proses awal untuk mendapatkan karyawan yang berkualitas setelah menentukan kualifikasi yang dibutuhkan dan akan membantu perusahaan mencapai tujuan.

Hasil yang didapatkan dari pengujian, wawancara dan observasi di PT. Indomarco Adi Prima menunjukkan bahwa praktik rekrutmen berjalan cukup baik. Sebelum membuka lowongan pekerjaan, para manajer menganalisis kebutuhan perusahaan dan karyawan, sehingga dapat menentukan kualifikasi yang harus ada pada calon karyawan. Semakin baik standart proses rekrutmen dengan indikator dasar sumber penarikan karyawan yang berpedoman pada posisi atau spesifikasi pekerjaan, sumber karyawan (internal dan eksternal), dan indikator metode penarikan karyawan, berupa strategi rekrutmen yang digunakan, maka produktivitas kerja karyawan akan meningkat dan dapat membantu tercapainya tujuan perusahaan. Menurut manajer SDM PT. Indomarco Adi Prima menentukan kualifikasi calon karyawan perlu disesuaikan dengan posisi yang akan ditempati, maka dari itu proses rekrutmen sangat memengaruhi produktivitas perusahaan.

\section{Pengaruh Penempatan Kerja terhadap Produktivitas Kerja Karyawan}

Penelitian memberikan hasil bahwa penempatan kerja membawa pengaruh signifikan positif terhadap produktivitas karyawan, yang berarti menerima H2. Penelitian ini didukung oleh Haryati \& Hajar (2016) dan Mandik \& Sendow (2019) yang membuktikan penempatan kerja memberi pengaruh signifikan positif terhadap produktivitas kerja karyawan. Ketepatan dalam menempatkan karyawan pada suatu jabatan akan menumbuhkan aura positif karyawan dalam bekerja, semangat karyawan yang tinggi dan motivasi bekerja yang baik akan meningkatkan produktivitas kerja karyawan. Penempatan karyawan yang dibantu proses rekrutmen dalam menarik karyawan untuk jabatan tertentu akan sangat membantu perusahaan dalam meningkatkan citra perusahaan. 
Novika Nur Rohmah \& Agus Frianto. Peran Rekrutmen dan Penempatan Kerja Pada PT. Indomarco Adi Prima Surabaya

Dari hasil wawancara dan observasi di PT. Indomarco Adi Prima, praktik penempatan kerja berjalan cukup baik. Perusahaan memiliki keyakinan atas penempatan karyawan yang sesuai akan meningkatkan produktivitas karyawan dalam melakukan tuntutan pekerjaan dalam perusahaan. Penarikan karyawan yang disesuaikan kualifikasi akan membantu proses penempatan kerja, karena penempatan jabatan yang kosong dijadikan acuan dalam penentuan kualifikasi yang digunakan rekrutmen.

\section{Pengaruh Rekrutmen dan Penempatan Kerja terhadap Produktivitas Kerja Karyawan}

Hasil penelitian menunjukkan adanya pengaruh secara simultan antara rekrutmen dan penempatan kerja terhadap produktivitas kerja karyawan, artinya $\mathrm{H} 3$ diterima. Penelitian ini didukung oleh Din \& Sumarauw (2018) bahwa rekrutmen dan penempatan kerja berpengaruh positif terhadap produktivitas kerja karyawan. Begitu juga Sari (2018), Syafitri \& Chairoel (2019), Romadloni (2019), dan Siregar et al. ( 2020), untuk mendapatkan karyawan yang berkualitas memerlukan penyaringan atau proses rekrutmen dan penempatan posisi karyawan yang tepat agar dapat menunjang produktivitas kerja karyawan dan perusahaan. Partisipasi rekrutmen dan penempatan kerja yang menunjang produktivitas kerja karyawan dianggap dapat meningkatkan produktivitas perusahaan dan meningkatkan citra perusahaan.

Hasil yang didapatkan dari pengujian, wawancara dan observasi di PT. Indomarco Adi Prima menunjukkan bahwa praktik rekrutmen bekerja sama dengan penempatan kerja telah berjalan dengan baik. Di mana semakin baik pelaksanaan rekrutmen dan penempatan kerja, maka produktivitas kerja karyawan juga akan meningkat. Hal ini dapat bisa digunakan acuan untuk mengetahui perubahan produktivitas kerja karyawan serta menolong perusahaan mengambil keputusan saat penilaian produktivitas.

\section{KESIMPULAN}

Penelian ini memberi kesimpulan yaitu: pertama, hubungan rekrutmen dengan produktivitas kerja karyawan di PT. Indomarco Adi Prima menunjukkan pengaruh yang signifikan positif. Artinya semakin baik sistem rekrutmen maka produktivitas kerja meningkat. Kedua, pengaruh signifikan positif juga ditunjukan oleh hubungan penempatan kerja terhadap produktivitas kerja karyawan PT. Indomarco Adi Prima Surabaya. Penempatan kerja yang tepat akan meningkatkan produktivitas kerja karyawan PT. Indomarco Adi Prima Surabaya. Ketiga, rekrutmen dan penempatan kerja memberi pengaruh positif dan signifikan terhadap produktivitas kerja karyawan PT. Indomarco Adi Prima. Kolaborasi antara rekrutmen dan penempatan kerja membantu meningkatkan produktivitas kerja karyawan dan berpengaruh terhadap produktivitas dan citra perusahaan.

Dari hasil ini perusahaan disarankan untuk dijadikan masukan atau bahan pertimbangan dalam melakukan proses rekrutmen guna memeroleh karyawan yang berkualitas yang diinginkan perusahaan dalam mencapai tujuan. Penelitian ini juga mengevaluasi pengaruh rekrutmen dan penempatan kerja karyawan terhadap produktivitas kerja yang akan membuka dimensi baru untuk meningkatkan produktivitas karyawan yang akan membantu untuk meningkatkan kemajuan perusahaan guna mengurangi persaingan dengan memahami kebutuhan dan masalah karyawan. Penelitian selanjutnya dapat mengembangkan dengan melihat variabel lain yang tidak diuji dalam penelitian ini seperti seleksi, kompensasi dan disiplin kerja.

\section{DAFTAR PUSTAKA}

Abiodun, O. M., Dan, I. S., \& Ayodele, N. C. (2020). Recruitment, Training and Employee Productivity in Nigerian Customs Service. Jurnal Studi Pemerintahan, 11(2), 202-228. https://doi.org/10.18196/jgp.112114

Afriandi, S. (2017). Meningkatkan Produktivitas Kerja di Perusahaan Jasa Survey. Jurnal Ilmiah Indonesia, 2(2), 133-143. https://doi.org/ISSN 2548-1398

Agustriyana, D. (2015). Analisis Faktor-Faktor Penempatan Karyawan Terhadap Kepuasan Kerja 
Novika Nur Rohmah \& Agus Frianto. Peran Rekrutmen dan Penempatan Kerja Pada PT. Indomarco Adi Prima Surabaya

Karyawan di PT Yuniko Asia Prima di Kota Bandung. Jurnal Ekonomi, Bisnis \& Entrepreneurship, 9(2), 158-178. https://doi.org/ISSN 2443-2121

Atmajati, A. R., \& Mansur. (2017). Pengaruh Rekrutmen , Seleksi , dan Penempatan Tenaga Kerja Terhadap Produktivitas Kerja Karyawan Pada PT. Bank Papua Jayapura. Future; Jurnal Manajemen Dan Akuntansi, 5(1), 1-7.

Din, S. T. N., \& Sumarauw, J. S. B. (2018). Pengaruh Rekrutmen, Seleksi, dan Penempatan Kerja terhadap Produktivitas Kerja di PT. HM. Sampoerna Tbk. Jurnal EMBA, 6(4), 4053-4062.

Elqadri, Z. M., Wardoyo, D. T. W., \& -, P. (2015). The Influence of Motivation and Discipline Work against Employee Work Productivity Tona'an Markets. Review of European Studies, 7(12), 5966. https://doi.org/10.5539/res.v7n12p59

Haryati, E., \& Hajar, S. (2016). Pengaruh Penempatan Karyawan Terhadap Produktivitas Kerja Pada PT . Pelabuhan Indonesia I ( Persero ). Jurnal Bisnis Administrasi, 05, 7-13.

Lestari, E. N., Sulton, M., \& Ariefin, M. S. (2018). Pengaruh Usia, Masa Kerja Dan Sistem Rekrutmen Terhadap Produktivitas Kerja Karyawan Pada PT. Ladang Hijau. E-Conversion Proposal for a Cluster of Excellence, 34.

Mandik, G. N., \& Sendow, G. M. (2019). Pengaruh Pendidikan, Penempatan Dan Kepuasan Kerja Terhadap Produktivitas Karyawan Pada PT. PLN (Persero) Rayon Paniki Manado. Jurnal EMBA: Jurnal Riset Ekonomi, Manajemen, Bisnis Dan Akuntansi, 7(3), 4367-4376. https://doi.org/10.35794/emba.v7i3.25088

Mey, K. (2017). Rekrutmen Tenaga Kerja. https://www.scribd.com/document/350313228/REKRUTMEN-TENAGA-KERJA-new-docx (diakses 12 februari 2021)

Muliawaty, L. (2019). Peluang dan Tantangan Sumber Daya Manusia di Era Distrupsi. Jurnal Ilmu Administrasi, 10, 1-11. https://doi.org/http://dx.doi.org/10.23969/kebijakan.v10i1.1416

Natalia, M. (2020, November). Produktivitas Tenaga Kerja RI Masih di Bawah ASEAN, Ini Sebab Butuh UU Ciptaker. Sindonews.Com. https://ekbis.sindonews.com/read/230160/34/produktivitas-tenaga-kerja-ri-masih-di-bawahasean-ini-sebab-butuh-uu-ciptaker-1605193906 (diakses 4 mei 2021)

Pranoto, E., Haryono, andy tri, \& Warso, moh mukeri. (2016). Pengaruh Rekrutmen, Stress Kerja dan Pemberian Insentif Terhadap Produktivitas Kerja dengan Komitmen Organisasi sebagai Variabel Intervening Pada PT. Ungaran Sari Garment Unit III Congol Karangjati. Journal Of Management, 2(2), 571-572. https://doi.org/10.4295/audiology.59.571

Pranutoko, B. (2016). Pengaruh pelaksanaan Rekrutmen Tenaga Kerja Terhadap Peningkatan Produktivitas Kerja Karyawan. Jurnal MAnajemen Dan Kewirausahaan, 1(1), 40-45.

Praskova, A., Creed, P. A., \& Hood, M. (2015). Career identity and the complex mediating relationships between career preparatory actions and career progress markers. Journal of Vocational Behavior, 87(December 2018), 145-153. https://doi.org/10.1016/j.jvb.2015.01.001

Sabrina, M. (2018). Mengapa Rekrutmen menjadi Sebuah Tugas Penting bagi Seorang Manajer Sumber daya Manusia. Dictio. https://www.dictio.id/t/mengapa-rekrutmen-menjadi-sebuahtugas-penting-bagi-seorang-manajer-sumber-daya-manusia/20745/2 (diakses 12 februari 2021)

Saputra, W. (2019). Peran SDM dalam revolusi 4.0. Kompasiana. 
Novika Nur Rohmah \& Agus Frianto. Peran Rekrutmen dan Penempatan Kerja Pada PT. Indomarco Adi Prima Surabaya

https://www.kompasiana.com/wahyuputrasa14/5d16f6ab097f3630513d0d32/peran-sdm-dalamrevolusi-industri-4-0\#: :text=Dalam hal ini sdm merupakan,menghadapi era revolusi industri 4.0 .\&text=Pertama adalah kualitas\%2C yaitu upaya,kerja yang berbasis teknologi (diakses 12 februari 2021)

Saretta, I. R. (2019). Manajemen Sumber Daya Manusia Sebagai Upaya Mencapai Target Organisasi. Cermati.Com. https://www.cermati.com/artikel/manajemen-sumber-daya-manusiasebagai-upaya-mencapai-target-organisasi (diakses 24 februari 2021)

Sari, S. S. (2020). The Effect of Work Training On Employee Work Productivity In The Department Of Village Community Empowerment Ogan Komering Ulu. International Journal of Economics, Business and Accounting Research (IJEBAR), 4(4), 340-349.

Sari, W. M. (2018). Pengaruh Rekrutmen Dan Penempatan Kerja Terhadap Produktivitas Kerja Karyawan Pada PT. Sindang Brothers Kota Lubuklinggau. Journal of Economic, Business and Accounting (COSTING), 1(2), 121. https://doi.org/https://doi.org/10.31539/costing.v1i2.213

Sarinah, Gultom R \& Thabah, A, A. (2016). The Effect of Recruitment and Employee Selection on Employee Placement and Its Impacts Towards Employee Performance at PT Sriwijaya Air. Jurnal Manajemen Transportasi \& Logistik (JMTranslog), 03(1), 1-10.

Siregar, M. N. S., Andriyani, P. R., Wellan, G. B. R., Limbong, S., \& Anggoro, M. A. (2020). Pengaruh Rekrutmen, Pelatihan, dan Konseling terhadap Produktivitas Kerja Karyawan pada PT. Telkom Akses Medan. Jurnal Ilmiah Universitas Batanghari Jambi, 20(3), 971-975. https://doi.org/10.33087/jiubj.v20i3.1086

Sunarsi, D. (2018). Pengaruh Rekrutmen, Seleksi Dan Pelatihan Terhadap Produktivitas Kerja Karyawan. Jurnal KREATIF : Pemasaran, Sumberdaya Manusia Dan Keuangan, 6(1), 14-31.

Suwarto. (2015). Pengaruh Seleksi Dan Penempatan Pegawai Terhadap Produktivitas Kerja Pegawai Di BMT Familier Kota Gajah Lampung Tengah. CNR-ISTI Technical Report, 9(1), 356-369. -

Syafitri, T. J., \& Chairoel, L. (2019). Pengaruh Rekrutmen, Seleksi, Penempatan Kerja Dan Kualitas Sdm Terhadap Produktivitas Kerja (Studi Pada Karyawan Bank Syariah Mandiri Kantor Cabang Padang). Jurnal Benefita, 4(3), 570. https://doi.org/10.22216/jbe.v4i3.4090

Zimmerman. (2018). Pengertian Revolusi Industri 4.0, Prinsip, dan Tantangan Revolusi Industri 4.0. Pelajaran.Co.Id. https://www.pelajaran.co.id/2019/31/pengertian-revolusi-industri-4-0-prinsipdan-tantangan-revolusi-industri-4-0.html (diakses 24 februari 2021) 